\title{
Biología del pasto rosado Melinis repens (Willd.) e implicaciones para su aprovechamiento o control. Revisión
}

\author{
Biology of natal grass Melinis repens (Willd.) and \\ implications for its use or control. Review
}

\author{
Alicia Melgoza Castilloa, Martha Irma Balandrán Valladaresa, Ricardo Mata-Gonzálezb, \\ Carmelo Pinedo Álvareza
}

\begin{abstract}
RESUMEN
El pasto rosado (Melinis repens) es una especie introducida de África que invade diversos ecosistemas. En México se encuentra en todos los Estados, y en Chihuahua es la especie dominante en extensas áreas de pastizales. Las invasiones reducen la calidad y cantidad de los productos y servicios del ecosistema. No se sabe exactamente cuándo llegó al continente americano. Dependiendo de las condiciones climáticas puede comportarse como anual o perenne de vida corta. Produce abundante semilla durante años con precipitaciones por debajo de lo normal comparados con años lluviosos. La germinación de la semilla puede ser en presencia de luz o sin ella, la máxima germinación es entre 20 a 35 ㅇ; a $-0.2 \mathrm{MPa}$ se inhibe la germinación y el fuego no la afecta. Bajo condiciones de humedad y en las primeras etapas de desarrollo presenta una relación raíz parte aérea de 1.13 a 1.90 y una tasa de crecimiento relativo de 0.0034 a $0.15 \mathrm{mg} \mathrm{g}^{-1} \mathrm{~d}^{-1}$; además, reduce biomasa en $70 \%$ cuando crece en suelo nativo comparado con suelo esterilizado. Si bien es un mal forraje por su valor nutricional, su principal uso es como forraje. Otros usos son ornamental, medicinal y como fito-remediador. La aplicación de fuego favorece su desarrollo y no se conoce un método de control. Por lo que el aprovechamiento como forraje es lo más viable. Al implementar una campaña de control es importante reducir el movimiento de esta especie como parte de las actividades humanas.
\end{abstract}

PALABRAS CLAVE: Invasión de plantas, Pastizales, Pasto rosado.

\begin{abstract}
Natal grass (Melinis repens) is an introduced specie from Africa that is invading different ecosystems. In Mexico, it is present all over the country and dominates large areas of grasslands. Plant invasion reduces quality and quantity of ecosystem goods and services. The knowledge of the biology of invasive species is a key factor when a management and control plan will be established. It is unknown when this specie arrived to America. Depending on climatic conditions this grass may behave as annual or perennial. Seed production is larger in years with precipitation below normal than in wet years. Germination takes place with or without light, optimum temperature is from 20 to $35 \stackrel{\circ}{\circ}$; at $-0.2 \mathrm{MPa}$ germination is inhibited, and fire does not affect seed germination. When moisture is not limited and during the early development, root:shoot ratios ranges from 1.13 to 1.90 and relative growth rate from 0.0034 to $0.15 \mathrm{mg} \mathrm{g-1}^{-1} \mathrm{~d}$; also, biomass is reduced when natal grass grows on native soil compared to sterilized soil. Although it is considered as poor forage, the main use is as pasture. Other uses reported include ornamental, medicinal, and fito-remediation. Fire favors its growth, and no control method is known. So far, grazing of natal grass is the most viable management. Additionally, when planning a control campaign it is important to reduce the movement of this specie as part of human activities.
\end{abstract}

KEY WORDS: Plant invasion, Grasslands, Natal grass.

Recibido el 17 de septiembre de 2013. Aceptado el 25 de noviembre de 2013.

a Departamento de Recursos Naturales, Facultad de Zootecnia y Ecología, UUACH. Perif. Francisco R. Almada km 1, Chihuahua, Chihuahua. México. cpinedo@uach.mx Correspondencia al último autor.

b Departament of Animal and Rangeland Science, Oregon State University. USA. 


\section{INTRODUCCIÓN}

El pasto rosado (Melinis repens) es una gramínea originaria de Sudáfrica que actualmente se presenta en todos los estados de la República Mexicana. En su lugar de origen se distribuye principalmente en sabanas, aunque también está presente en pendientes rocosas, barrancos y a las orillas de riachuelos; comúnmente en hábitats con suelos poco profundos y clima cálido y $\operatorname{seco}(1,2)$. El pasto rosado se presenta en cualquier tipo de exposición, incluyendo las pendientes más cálidas y secas cuando ocurre en asociación con otras especies dominantes(2). La principal amenaza para este pasto en su lugar de origen, es el sobrepastoreo y la compactación del suelo provocado por el ganado y fauna que emigra en determinadas épocas del año(3).

\section{HISTORIA DE LA DISPERSIÓN DEL PASTO ROSADO}

El pasto rosado fue introducido a Florida en Estados Unidos de América como planta ornamental en 1866(4); aunque otro reporte de su arribo es en 1893(5). A partir del año de 1903, esta especie se introdujo al suroeste de Estados Unidos de América; y ahora es reportada como invasora, tanto en esta zona como en el norte de México(6) y naturalizada en los estados de Florida, Nuevo México y Arizona(7). Existen diferentes criterios para considerar a una planta naturalizada, exótica e invasora y el pasto rosado cumple todos estos criterios(8). Una especie invasora es aquella que su distribución se extiende a otro lugar geográfico o hábitat diferente a su lugar de origen; exótica es una especie introducida por actividades antropogénicas. Especie naturalizada es aquélla que logra reproducirse constantemente, y mantener poblaciones por más de un ciclo de vida por al menos un periodo de 10 años posteriores a su primera introducción. En Florida, a partir del 2005 el pasto rosado cambió su estatus de posible invasor a invasor(9), posicionándolo dentro de la categoría I: especies

\section{INTRODUCTION}

Natal grass (Melinis repens) is a Gramineae (Poaceae) from South Africa that currently has a presence in all the states of Mexico. In its place of origin it distributes mainly in savanna, though it is also present in rocky cliffs, gullies and along streams; commonly in habitats with shallow soils and warm and dry weather $(1,2)$. Natal grass is present in any kind of exposition, including the warmest and driest slopes when it occurs in association with other dominant species (2). The main threat for this grass in its place of origin is overgrazing and soil compaction caused by cattle and the fauna that migrates in some seasons of the year( 3 .

HISTORY OF THE DISPERSAL OF NATAL GRASS

Natal grass was introduced to Florida in the United States as an ornamental plant in 1866(4); another report of its arrival is from 1893(5). Starting on 1903, this species was introduced to the Southeast of the United States; now it is reported as an invasive species, both in this area and in the North of Mexico(6) and as a naturalized plant in the states of Florida, New Mexico and Arizona(7). There are different criteria to consider a plant as naturalized, exotic and invasive and the rose natal grass meets all these criteria(8). An invasive species is that whose distribution extends to a geographical site or habitat different to its place of origin; an exotic one is a species introduced by anthropogenic activities. A naturalized species is that which manages to reproduce constantly and to maintain populations during more than one life cycle during a period of at least $10 \mathrm{yr}$ after its first introduction. In Florida, starting on 2005 natal grass changed its status of potential invasive to invasive(9), placing it in category I: invasive exotic species that cause alterations and displacement of native species, which cause changes in the ecologic structure and function of the invaded habitat(7).

Since 1977, natal grass was present in Nuevo León $(10)$, therefore its presence in this State 
exóticas invasoras que provocan alteraciones y desplazamiento de especies nativas, lo que ocasiona cambios en la estructura y función ecológica del hábitat invadido(7).

Desde 1977, el pasto rosado estaba presente en Nuevo León(10), por lo que su presencia en este estado como en Tamaulipas puede ser desde los 60s, suponiendo que probablemente entró a México a través de este último Estado. En el libro "La Flora del Valle de México" no es reportada en los $70 \mathrm{~s}^{(11)}$. Posteriormente, en 1989, se reporta la distribución del pasto rosado principalmente en los estados de Coahuila, Aguascalientes, Jalisco y Nuevo León(12). En el estado de Chihuahua no se reportó en el primer listado de gramíneas en los 70s(13); y es hasta 1986 que se menciona para el estado como invasora(14). La revisión de ejemplares de herbario indudablemente puede dar una mejor información sobre la secuencia histórica de la invasión del pasto rosado en México.

La Comisión Nacional para el Conocimiento y Uso de la Biodiversidad (CONABIO) considera al pasto rosado como una especie invasora, aunque no se cuenta con suficiente información ecológica, de manejo y control de esta planta(15). Otros reportes de invasiones en el mundo incluyen Zimbawe(16), Argentina, Bolivia, Brasil, Paraguay, Uruguay(17) y el resto de América del sur y el Caribe(18). En México también es considerada entre las especies invasoras de alto impacto a la biodiversidad (19); actualmente se encuentra en todos los estados del país(20).

El pasto rosado puede establecerse en diversos ambientes tales como zonas templadas, áridas, selva baja caducifolia, zonas de cultivos y orillas de carreteras $(5,21)$. Además, esta especie se puede establecer en áreas recuperadas de minas de fosfato y en suelos recién cultivados; sin embargo, tiende a desaparecer al aumentar la acidez del suelo a niveles cercanos a $\mathrm{pH}$ 5(4). Por su amplia adaptabilidad, el pasto rosado se ha convertido en un componente and in Tamaulipas may well date from the 60s, assuming that probably it entered Mexico through this last State. In the book "La Flora del Valle de México" it is not reported in the $70 s^{(11)}$. Later, in 1989, the distribution of natal grass is reported mainly in the states of Coahuila, Aguascalientes, Jalisco and Nuevo León(12). In the State of Chihuahua it was not reported in the first grass list of the $70 \mathrm{~s}^{(13)}$; it is until 1986 that it is mentioned in the state as an invasive species(14). The review of herbarum specimens may undoubtedly provide better information about the historical sequence of natal grass invasion in Mexico.

The National Commission for the Knowledge and Use of the Biodiversity (CONABIO) considers natal grass as an invasive species, although there is not enough ecological, management and control information about this plant(15). Other reports of invasions in the world include Zimbabwe(16), Argentina, Bolivia, Brazil, Paraguay, Uruguay(17) and the rest of South America and the Caribbean(18). In Mexico it is also considered among the invasive species with high impact on biodiversity(19); currently it is found in all the states of the country(20).

Natal grass may establish in different environments such as temperate and arid zones, low elevation deciduous forests, crop areas and next to highways $(5,21)$. In addition, this species may establish in areas recovered from phosphate mines and recently sowed soils; however, it tends to disappear when the soil's acidity

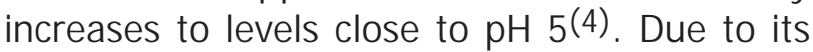
wide adaptability, natal grass has become a common component in many vegetable communities, and it may potentially represent ecological problems similar to buffel grass (Cenchrus ciliare), which is also an African invasive species from warm regions. The buffel grass invasion creates a positive feedback in areas where they have tried to control it with fire(22). This response causes changes in the native vegetation and adjustments in grazing management. Buffel grass has invaded several areas in Sonora, among them protected natural 
común en muchas comunidades vegetales, y potencialmente podría representar problemas ecológicos similares al zacate buffel (Cenchrus ciliare), que es también una especie invasora de origen africano y de regiones cálidas. La invasión de buffel crea una retroalimentación positiva en áreas donde se ha tratado de controlarlo con fuego(22). Esta respuesta provoca cambios en la vegetación nativa y ajustes en el manejo del pastoreo. El buffel ha invadido diversas áreas en Sonora, entre ellas áreas naturales protegidas(23); se predice que puede invadir matorrales xorófitos, mezquitales y bosque tropical deciduo(24). Sin embargo, el potencial de invasión y la agresividad del pasto rosado parecen ser menores que las del zacate buffel(6).

\section{BIOLOGÍA DEL PASTO ROSADO}

Los nombres comunes del pasto rosado en México dependen de la región en la que se encuentra, puede ser llamado: zacate rosado, hierba de la lana, pasto carretero y rosado. La taxonomía de esta gramínea ha cambiado, por lo que en anterior literatura fue nombrada como: Erianthus repens (Willd.) P. Beauv., Melinis rosea Hack., Monachyron roseum (Ness) Parl., Monachyron tonsum (Ness) Parl., Panicum roseum (Ness) Steud, P. sphacelatum (Benth.) Steud., P. teneriffae var. rosea (Ness) Steud., Rhynchelytrum repens (Willd.) C.E. Hubb., $R$. repens var. roseum (Ness) Chiov., $R$. roseum (Nees) Stapf \& Hubb., $R$. tonsum (Nees) Lanza $\&$ Mattei, Saccharum repens Willd., Tricholaena repens (Willd.) Hitchc., T. repens var. rosea (Ness) Alberts., T. rosea Ness y $T$. tonsa Ness(18). Correll y Johnston(25) señalan que de las 37 especies del género Rhynchelytrum del viejo mundo, $R$. repens es la de más amplia distribución.

El pasto rosado se comporta como anual o perenne de vida corta $(14,26-29)$. La altura promedio es de 50 a $60 \mathrm{~cm}$, aunque puede alcanzar hasta poco más de $100 \mathrm{~cm}$ de altura; si bien generalmente es erecta, en ocasiones presenta tallos geniculados en su base. La lígula areas (23); it is predicted that it may invade xerophytic scrub, mesquite areas and deciduous tropical forest(24). However, the invasive potential and the aggression level of natal grass seem to be lower than the buffel grass(6).

\section{NATAL GRASS BIOLOGY}

Common names for natal grass in Mexico depend of the region, it may be called: zacate rosado, hierba de la lana, pasto carretero and pasto rosado. The taxonomy of this gramineae has changed, therefore in previous studies it has been called: Erianthus repens (Willd.) P. Beauv., Melinis rosea Hack., Monachyron roseum (Ness) Parl., Monachyron tonsum (Ness) Parl., Panicum roseum (Ness) Steud, P. sphacelatum (Benth.) Steud., P. teneriffae var. rosea (Ness) Steud., Rhynchelytrum repens (Willd.) C.E. Hubb., $R$. repens var. roseum (Ness) Chiov., $R$. roseum (Nees) Stapf \& Hubb., $R$. tonsum (Nees) Lanza \& Mattei, Saccharum repens Willd., Tricholaena repens (Willd.) Hitchc., T. repens var. rosea (Ness) Alberts., T. rosea Ness and T. tonsa Ness(18). Correll and Johnston(25) point out that out of the 37 species of the Old World genus Rhynchelytrum, $R$. repens has the widest distribution.

Natal grass behaves as an annual or short life perennial plant $(14,26-29)$. The average height is 50 to $60 \mathrm{~cm}$, though it may reach a little more than $100 \mathrm{~cm}$; although it is generally erect, occasionally it presents geniculate stems at its base. The ligule is pubescent, with leaves glabrous or with little trichomes, 6 to $20 \mathrm{~cm}$ long and 0.2 to $0.7 \mathrm{~cm}$ wide. The inflorescence is a panicle up to $25 \mathrm{~cm}$ long, with several spikelets, 0.3 to $0.5 \mathrm{~mm}$ long, covered by soft rose hairs that in mature age become white to silver color. This species is commonly reported next to highways $(14,26,27)$; however it currently is invading areas with native vegetation, and the affected area is not quantified in Mexico(30), where it is located at elevations from 0 to $2,500 \mathrm{~m}$, preferably in sandy soils(15). In Chihuahua, the BIOCLIM model applied to 129 records of the rose natal grass detected tan more than $60 \%$ 
es pubescente, hojas glabras o con pocas vellosidades, de 6 a $20 \mathrm{~cm}$ de largo y 0.2 a 0.7 $\mathrm{cm}$ de ancho. La inflorescencia es una panícula hasta de $25 \mathrm{~cm}$ de largo, con numerosas espiguillas de 0.3 a $0.5 \mathrm{~mm}$ de largo, cubiertas por vellosidades suaves color rosa que en la madurez se vuelven color banco a plateado. Esta especie es comúnmente reportada a lo largo de carreteras $(14,26,27)$; sin embargo, actualmente se encuentra invadiendo áreas con vegetación nativa sin que se tenga cuantificada la extensión afectada en México(30), donde se localiza de 0 a 2,500 msnm, preferentemente en suelos arenosos(15). En Chihuahua, el modelo BIOCLIM aplicado en 129 registros del pasto rosado detectó que más del $60 \%$ de los registros se presentan entre los 1,500 a 1,700 m, pendientes menores de $30 \%$ y exposiciones sur(31). En regiones tropicales se ha encontrado que se desarrolla mejor en áreas a lo largo de caminos que en otros tipos de hábitat(5); también altas densidades de arbustos no facilitan su establecimiento y desarrollo.

\section{Características}

A pesar de ser una maleza en diferentes partes del mundo, poco se conoce sobre las características específicas que el pasto rosado presenta para ser una planta invasora exitosa. Diversos trabajos han reportado características en plantas que favorecen la invasión, tales como: amplio rango de tolerancia a temperaturas altas(32), rasgos de plasticidad fenotípica(33), diferentes formas de reproducción (34), periodos de vida cortos, rápido crecimiento, fácil dispersión y bancos de semillas persistentes(35). Sin embargo, estas características pueden variar entre las diferentes especies y hábitats donde se presentan. De 40 características en plantas invasoras, los aspectos de reproducción, tolerancia al ambiente y año de arribo en un lugar, fueron las que sobresalieron en 388 especies invasoras evaluadas(36). Por otra parte, además de las características que puedan influir en el éxito de una planta invasora, una nueva especie en un ecosistema no tiene los of the records are between 1,500 to $1,700 \mathrm{~m}$, with slopes under $30 \%$ and South expositions(31). In tropical regions it has been found that it develops better in areas along roads than in other types of habitats(5); also the high density of bushes does not facilitate its establishment and development.

\section{Characteristics}

Despite being considered as weed in different parts of the world, little is known about the specific characteristics of natal grass for being a successful invasive plant. Several reports have found characteristics in plants that favor invasion, such as: a wide range of tolerance to high temperatures(32), traits of phenotypic plasticity(33), different forms of reproduction(34), short life periods, fast growth, easy dispersion and persistent seed banks(35). However, these characteristics may vary among the different species and habitats where they are present. Out of 40 characteristics in invasive plants, reproduction aspects, tolerance to the environment and year of arrival to a place were the most relevant in 388 invasive species evaluated(36). On the other hand, in addition to the characteristics that may influence the success of an invasive plant, a new species in an ecosystem does not have predators or competitors like in its place of origin(37).

\section{Seed Production}

In the case of invasive grasses it has been pointed out that the high seed production is an important survival and dispersion trait(38). Natal grass may produce $113.5 \mathrm{~kg} \mathrm{ha}^{-1}$ of seed in its first year, when it behaves as a perennial plant(4). At the central part of Mexico it was found a production of 112.8 to $206.5 \mathrm{~kg}$ ha-1; in addition, the high production was obtained in years with below average rainfall(20). Natal grass seeds are light; a gram contains from 1,311 to $1,417(21)$. The small weight of the seed and its plumose characteristics are attributes for an efficient and fast dispersion $(39,40,41)$. 
depredadores o competidores como en su lugar de origen(37).

\section{Producción de semilla}

En el caso de gramíneas invasoras se ha señalado que la alta producción de semilla es una característica importante de sobrevivencia y dispersión(38). El pasto rosado puede alcanzar una producción de semilla de $113.5 \mathrm{~kg}$ ha-1 en su primer año, cuando se comporta como perenne(4). En una población del centro de México se encontró una producción de 112.8 a $206.5 \mathrm{~kg} \mathrm{ha}-1$; además, las altas producciones se obtuvieron en años con precipitación por debajo de lo normal(20). Las semillas de rosado son livianas; un gramo contiene de 1,311 a $1,417(21)$. El peso de la semilla y su característica plumosa le confieren atributos para una eficiente y rápida dispersión $(39,40,41)$.

La semilla del pasto rosado recolectada directamente de la inflorescencia antes de ser dispersada presenta un $6 \%$ de viabilidad mientras que la semilla recolectada del suelo tiene un $49 \%$ de viabilidad(4). En recolectas realizadas en Chihuahua se ha encontrado una viabilidad que va del 40 al $46 \%(42)$; mientras que en Aguascalientes fue 36 a $54 \%(20)$. La viabilidad se reduce de 9 a $12 \%$ cuando la semilla es expuesta por $72 \mathrm{~h}$ en el rumen de bovinos(42).

Las semillas del pasto rosado, como las de muchas otras especies, requieren de un periodo de maduración después de la caída al suelo $(20,21)$. Se ha reportado un incremento en la germinación de 6 a 25 \% cuando se almacenó por un periodo de 15 semanas(4). Este trabajo se realizó con germoplasma de Florida y reportan que la germinación no se afecta por presencia o ausencia de luz, la temperatura óptima para germinación está entre los 20 y 35 o $\mathrm{C}$, el pH óptimo entre 6 a 8 y se inhibe a pH de 4 a 10. También puede germinar cuando se encuentra a una profundidad hasta de $5 \mathrm{~cm}$, y a potenciales osmóticos inferiores a $-0.2 \mathrm{MPa}$ no germina. En otra investigación en esta
Natal seeds collected directly from the inflorescence before it is dispersed present $6 \%$ viability while the seed collected from the ground have $49 \%$ viability(4). In collection in Chihuahua it has been found a viability from 40 to $46 \%$ (42); while in Aguascalientes it was 36 to $54 \%$ (20). Viability is reduced from 9 to $12 \%$ when the seed is exposed for $72 \mathrm{~h}$ in bovine rumen(42).

Natal grass seeds, as well as many other species' require a maturity period after they fall to the ground $(20,21)$. It has been reported an increase in germination from 6 to $25 \%$ when it was stored for a period of $15 \mathrm{wk}^{(4)}$. This work was performed with germplasm from Florida and they report the germination is not affected by the presence or absence of light, the optimal temperature for germination is between 20 and $35 \stackrel{\circ}{ } \mathrm{C}$, the optimal $\mathrm{pH}$ is between 6 and 8 and it is inhibited at a pH from 4 to 10. It may also germinate when it is found at a depth of up to $5 \mathrm{~cm}$, and at osmotic potentials under -0.2 $\mathrm{MPa}$ it does not germinate. In another investigation on this species no differences were found between the germination of the seed exposed and not exposed to fire ${ }^{(42)}$. In both cases, seeds germinate slowly, which give them competitive advantages in places with scarce and irregular rainfall such as in arid areas(43). The seed bank in the soil is maintained and it takes advantage of any event of rain without risking the total of seeds on the ground.

Biomass production

Natal grass is a $\mathrm{C}_{4}$ plant, with a high $\mathrm{CO}_{2}$ assimilation capacity and a fast increase of the foliar area(44). Natal grass biomass production varies depending on the rainfall(4). In rainy years it has been registered a shoot biomass production from 1,736 to $2,913 \mathrm{~kg} \mathrm{ha}-1$ and in dry years from 707 to $1,488 \mathrm{~kg}(20)$. This species presents a root/shoot ratio of 1.13 to 1.90 , at least in the first stages of growth(42). Other studies report for developed grasses a root/ shoot ratio of 3 in $B$. gracilis and 2.5 in Hilaria mutica(45), 4.3 in Sorghastrum nutans and 4.9 in Bouteloua curtipendula(46) and 5.5 in 
especie, no se encontraron diferencias entre la germinación de semilla expuesta y no expuesta al fuego(42). En ambos casos, las semillas germinan lentamente, lo que le da ventajas competitivas en lugares con lluvias escasas e irregulares como en zonas áridas(43). El banco de semillas en suelo se mantiene y aprovecha cualquier evento de lluvia sin arriesgar el total de semillas en suelo.

\section{Producción de biomasa}

El pasto rosado es una planta $\mathrm{C}_{4}$, con alta capacidad de asimilación de $\mathrm{CO}_{2}$ y rápido incremento del área foliar(44). La producción de biomasa del pasto rosado varía dependiendo de la precipitación(4). En años lluviosos se ha registrado una producción de biomasa aérea de 1,736 a $2,913 \mathrm{~kg} \mathrm{ha}^{-1}$ y en años secos de 707 a 1,488 kg ha-1(20). Esta especie presenta una relación raíz parte aérea de 1.13 a 1.90, al menos en las primeras etapas de crecimiento (42). Otros trabajos reportan para gramíneas ya desarrolladas una relación raíz parte aérea de 3 en $B$. gracilis y 2.5 en Hilaria mutica(45), 4.3 en Sorghastrum nutans y 4.9 en Bouteloua curtipendula(46) y 5.5 en Sporobolus airoides, 4 en Distichlis spicata y 3 en Leymus triticoides(47). Los valores altos representan mayor inversión de biomasa en raíces para la búsqueda de recursos $(48,49)$. Al comparar los valores obtenidos en el pasto rosado de la relación raíz parte aérea es importante mencionar que estos fueron obtenidos en los primeros 120 días de crecimiento. Si bien no se tiene documentado, las condiciones ambientales indudablemente determinan en esta especie que poblaciones 0 individuos en las poblaciones se comportan como anuales, y por lo tanto invierten menos energía en la producción de raíces.

Las especies nativas de zonas áridas y pastizales semiáridos que están adaptadas a suelos pobres en nutrimentos muestran una tasa de crecimiento relativo inferior a las invasoras, y la magnitud de estas diferencias se intensifica con el incremento de la disponibilidad de
Sporobolus airoides, 4 in Distichlis spicata and 3 in Leymus triticoides(47). The high values represent a higher biomass investment in roots for the search of resources $(48,49)$. When the values obtained for the root/shoot ratio for natal grass are compared, it is important to mention that these were obtained in the first $120 \mathrm{~d}$ of growth. Although it is not well documented, the environmental conditions without a doubt determine in this species what populations or individuals in the populations behave as annual and therefore invest less energy in root production.

Native species in arid areas and semiarid grasslands that are adapted to soils poor in nutrients show a relative growth rate inferior than invasive species, and the magnitude of these differences is intensified with the increase in resource availability(49). A high relative growth rate (RGR) of invasive species allows them to occupy and to capture resources fast, and to reduce the time between vegetative growth and reproduction(49). Two species of perennial invasive grasses present RGR between 51 and $43 \mathrm{mg} \mathrm{g}^{-1} \mathrm{~d}^{-1(48)}$. In another study where six native plants and six introduced plants were evaluated, the RGR was between 40 and 14 $\mathrm{mg} \mathrm{g}^{-1} \mathrm{~d}^{-1}$, the ones with the highest value were the introduced plants(49). Natal grass presented RGR values of $0.0034 \mathrm{mg} \mathrm{g}^{-1} \mathrm{~d}^{-1}$ in the period from d 10 to $\mathrm{d} 20$ and $0.036 \mathrm{mg}$ between $d 100$ and 120(42). The highest RGR was presented in the stage of $d \quad 60$ and 80 with values of $0.15 \mathrm{mg}$. Based on these data it may be estimated that natal grass, despite being an invasive species, is a slow growth plant, related to unfavorable environments (water and nutrient limitations), which favors its establishment in arid areas(50). Although this is a characteristic attributed to invasive species(51), in the case of natal grass the RGR does not seem to contribute to its success as an invasive plant.

Despite the importance of the studies about the relationship between plants and microorganisms $(52,53,54)$, little is known about this relationship in invasive plants. Natal grass 
recursos(49). La alta tasa de crecimiento relativo (TCR) de las especies invasoras le permite ocupar y capturar recursos rápidamente, y reducir el tiempo entre el crecimiento vegetativo y la reproducción(49). Dos especies de gramíneas perenes invasoras presentan TCR entre 51 y 43 $\mathrm{mg} \mathrm{g}^{-1} \mathrm{~d}^{-1}(48)$; mientras que otro estudio donde se evaluaron seis plantas nativas y seis introducidas la TCR fue entre 40 y $14 \mathrm{mg}$, de éstas, las de más alto valor fueron las plantas introducidas(49). El pasto rosado presentó valores de TCR de $0.0034 \mathrm{mg} \mathrm{g}^{-1} \mathrm{~d}^{-1}$ en el periodo de los 10 a los 20 días y de $0.036 \mathrm{mg}$ entre los 100 y 120 días(42). La mayor TCR se presentó en la etapa de los 60 y 80 días con valores de $0.15 \mathrm{mg}$. Con base en estos datos se puede estimar que el pasto a pesar de ser una especie invasora, es una planta de lento crecimiento, que está relacionada con ambientes poco favorables (limitaciones en agua y nutrimentos), lo que le favorece establecerse en zonas áridas(50). Si bien ésta es una característica que se atribuye a especies invasoras(51), en el caso del rosado la TCR no parece contribuir a su éxito como invasora.

A pesar de la importancia de los estudios sobre la relación entre raíces de plantas y microorganismos $(52,53,54)$, poco se conoce sobre esta relación en plantas invasoras. El pasto rosado reduce su producción de biomasa aérea y radicular en $70 \%$ cuando crece en suelo nativo comparado con su crecimiento en suelo esterilizado; mientras lo contrario se observó en pastos nativos(21). Esto sugiere que el pasto rosado no se beneficia de la misma comunidad microbiana que otros pastos nativos y que al contrario, una comunidad microbiana deteriorada puede contribuir a su establecimiento.

\section{APROVECHAMIENTO O CONTROL}

Uno de los principales aprovechamientos del pasto rosado es como fuente de forraje. Entre los primeros reportes se le dio un valor forrajero que iba de bueno(12) a regular(26) pero sólo durante la época de lluvia, que es cuando presenta mayor biomasa. Sin embargo, literatura más reciente lo considera mal forraje $(28,29,30)$. reduces its shoot and root biomass production $70 \%$ when it grows in native soil compared with sterilized soil; the opposite was observed in native grasses(21). This suggests that natal grass does not benefit from the same microbial community than other native grasses, and on the contrary, a deteriorated microbial community may contribute to its establishment.

\section{USE OR CONTROL}

One of the main uses of natal grass is as a source of forage. Some studies report a forage value that ranged from good(12) to regular(26) for this specie; but only during the rainy season, when it presents greater biomass. However, most recent literature considers it bad forage $(28,29,30)$.

Natal grass presents the following amounts of macro and micro nutrients: $47.40 \%$ of $\mathrm{C}$, $1.40 \%$ of $\mathrm{N}, 0.19 \mathrm{~g} \mathrm{~kg}^{-1}$ of $P, 1.14 \mathrm{~g} \mathrm{~kg}^{-1}$ of $\mathrm{K}, 0.21 \mathrm{~g} \mathrm{~kg}^{-1}$ of $\mathrm{Ca}, 0.34 \mathrm{~g} \mathrm{~kg}^{-1}$ of $\mathrm{Mg}, 0.16$ $\mathrm{g} \mathrm{kg}^{-1}$ of S, $16 \mathrm{mg} \mathrm{kg}^{-1}$ of $\mathrm{Cu}, 78 \mathrm{mg} \mathrm{kg}^{-1}$ of $\mathrm{Zn}, 1,070 \mathrm{mg} \mathrm{kg}^{-1}$ of $\mathrm{Fe}$ and $166 \mathrm{mg} \mathrm{kg}^{-1}$ of $\mathrm{Mn}$; the $\mathrm{C} / \mathrm{N}$ ratio was $34.07^{(55)}$. Based on the $\mathrm{N}$ content and when applying the conversion for raw protein, the value obtained is $8.75 \%$ (56). Our own analysis determined that the protein content in the growth stage goes from 4 to $6 \%$. When comparing these values to the 12 to $15 \%$ of raw protein in the blue grama grass (Bouteloua gracilis), this characteristic may be one of the causes for the blue grama grass to be preferred over natal grass(57); which favors the displacement of the native species. In addition to protein content, digestibility is important and this variable depends on the presence of lignified material. Plants with high leaf/stem ratio are less digestible and not consumed by livestock(58). Although the biomass distribution has not being quantified, natal grass presents a high leaf/stem ratio, it can be easily observed in the field. Natal grass presented low values in specific foliar area compared with another African grass, Eragrostis lehmanniana that presents invasion in grasslands(21). The low leaf/stem ratio and the protein content 
El pasto rosado presenta las siguientes cantidades de macro y micro nutrientes: $47.40 \%$ de $C, 1.40 \%$ de $\mathrm{N}, 0.19 \mathrm{~g} \mathrm{~kg}^{-1}$ de $\mathrm{P}, 1.14 \mathrm{~g}$ $\mathrm{kg}^{-1}$ de $\mathrm{K}, 0.21 \mathrm{~g} \mathrm{~kg}^{-1}$ de $\mathrm{Ca}, 0.34 \mathrm{~g} \mathrm{~kg}^{-1} \mathrm{de}$ $\mathrm{Mg}, 0.16 \mathrm{~g} \mathrm{~kg}^{-1}$ de $\mathrm{S}, 16 \mathrm{mg} \mathrm{kg}^{-1}$ de $\mathrm{Cu}, 78$ $\mathrm{mg} \mathrm{kg}^{-1}$ de $\mathrm{Zn}, 1,070 \mathrm{mg} \mathrm{kg}^{-1}$ de Fe y $166 \mathrm{mg}$ $\mathrm{kg}^{-1}$ de $\mathrm{Mn}$; la relación $\mathrm{C} / \mathrm{N}$ fue de $34.07(55)$. Con base en el contenido de $\mathrm{N}$ y al aplicar la conversión para proteína cruda, el valor obtenido es de $8.75 \%(56)$. Nuestros propios análisis determinaron que el contenido de proteína en la etapa de crecimiento va de 4 a $6 \%$. Al comparar estos valores con el 12 a $15 \%$ de proteína cruda en el pasto navajita (Bouteloua gracilis), esta característica puede ser una de las causas por las que es preferido el pasto navajita sobre el pasto rosado(57); lo que favorece el desplazamiento de la especie nativa. Además del contenido de proteína es importante la digestibilidad, el valor de esta variable depende de la presencia de material lignificado. Plantas con altas proporciones de tallo: hoja son menos digestibles y poco consumidas por el ganado(58). A pesar de no estar cuantificada la distribución de biomasa, el pasto rosado presenta alta proporción de tallos en relación a hoja a simple vista. El pasto rosado presentó valores bajos en área foliar específica comparado con otro pasto africano, Eragrostis lehmanniana, que presenta invasión en pastizales(21). La baja proporción de follaje en relación a tallos y el contenido de proteína, indudablemente contribuyen a que esta especie sea catalogada como mal forraje.

Independientemente del valor forrajero del rosado, las opiniones obtenidas por los ganaderos a través de reuniones de campo son variadas. Los ganaderos con ranchos invadidos con esta especie lo consideran forraje importante, ya que es su única fuente de forraje. Mientras que en los ganaderos con ranchos dominados por pastizal nativo, ven al pasto rosado como una amenaza. Un aspecto importante para determinar el valor como forraje de esta especie sería comparar costos de producción entre un rancho con invasión y otro sin él. En 1999, en el estado de Chihuahua se without a doubt contribute to this species being considered as bad fodder.

Independently of the forage value of natal grass, the opinions obtained from ranchers through field meetings are varied. Cattle raisers who have been invaded by this species consider it important forage, since it is their only source of forage. Meanwhile, the cattle raisers with native grasses see the natal grass as a threat. An important aspect to determine the value of this species as forage would be to compare the production costs of an invaded ranch and a free one. In 1999, in the state of Chihuahua it was determined that the average cost of production of a kilogram of meat was $\$ 15.00$; ranging between $\$ 3.60$ and 46.30 pesos $(59)$. The main problem found in this work was: diminished vegetal productivity, loss of the native perennial vegetal cover and lack of knowledge of the forage potential of the range land.

On the other hand, in the invaded places, natal grass protects the soil from erosion. It would be important to quantify the rates of change in the quantity and quality in relation to erosion, biogeochemical cycles, and rainfall infiltration in relation to the presence of natal grass as it has been done with other invasive plants $(60,61,62)$. This information is necessary to develop plant control or invasion prevention plans that not only affect the reaping of products from ecosystems, but also environmental services.

In Brazil, natal grass is used as a remedy in the treatment of diabetes. In a study performed with an extract of several parts of the plant it was found that plasma glucose levels in diabetic mice had been reduced $(63,64)$.

Natal grass has been reported with a potential in phytoremediation(65). In plants that grown next to highways the following amounts of trace metals have been determined in the roots: 61.1 $\mathrm{mg} \mathrm{kg}^{-1}$ of $\mathrm{Cu}, 97.3 \mathrm{mg} \mathrm{kg}^{-1}$ of $\mathrm{Pb}, 28.6 \mathrm{mg}$ $\mathrm{kg}^{-1}$ of $\mathrm{Ni}$ and $729 \mathrm{mg} \mathrm{kg}^{-1}$ of $\mathrm{Zn}$. The $\mathrm{Zn}$ was also found present in the stems' tissue. In 
determinó que el costo promedio de producción de un kilogramo de carne fue de \$15.00; con rangos de $\$ 3.60$ y 46.30 pesos(59). La problemática principal encontrada en este trabajo fue: disminución de la productividad vegetal, pérdida de la cubierta vegetal nativa perenne y desconocimiento del potencial forrajero del agostadero.

Por otra parte, en los lugares invadidos, el pasto rosado cumple con funciones ecológicas, dado que protege al suelo de la erosión. Sería importante cuantificar las tasas de cambio en la cantidad y calidad en relación a erosión, ciclos biogeoquímicos, e infiltración de la lluvia en relación a la presencia del pasto rosado, como se ha hecho en otras plantas invasoras $(60,61,62)$. Esta información es necesaria para desarrollar planes de control o prevención de invasión de plantas que no solo afecten económicamente la cosecha de productos de los ecosistemas, sino también los servicios ambientales.

En Brasil, el pasto rosado es utilizado como remedio para el tratamiento de la diabetes. En un estudio realizado con extracto de diversas partes de la planta se encontró que habían disminuido los niveles de glucosa en plasma en ratones diabéticos $(63,64)$.

El pasto rosado ha sido reportado con potencial en fitoremediación(65). En plantas que crecen a lo largo de carreteras se han determinado en raíz las siguientes cantidades de metales traza: $61.1 \mathrm{mg} \mathrm{kg}^{-1}$ de $\mathrm{Cu}, 97.3 \mathrm{mg} \mathrm{kg}^{-1}$ de $\mathrm{Pb}, 28.6$ $\mathrm{mg} \mathrm{kg}^{-1}$ de Ni y $729 \mathrm{mg} \mathrm{kg}^{-1}$ de $\mathrm{Zn}$. El Zn se encontró también presente en el tejido de los tallos. En otro estudio realizado con diferentes sedimentos de suelo contaminado por metales se encontró que clasifica al rosado como hiperacumulador de $\mathrm{Cd}$ con $90 \mathrm{mg} \mathrm{kg}^{-1}$ y $\mathrm{Zn}$ con $1,450 \mathrm{mg} \mathrm{kg}^{-1(66)}$.

Otro uso reportado de esta gramínea es el ornamental(12). Por comentarios entre pobladores rurales en Chihuahua, el color de la espiga llama la atención por lo que se cortan another study performed with different metal contaminated soil sediments it was found that natal grass is classified as hyperaccumulator of $\mathrm{Cd}$ with $90 \mathrm{mg} \mathrm{kg}^{-1}$ and of $\mathrm{Zn}$ with $1,450 \mathrm{mg}$ $\mathrm{kg}^{-1(66) \text {. }}$

Another use reported for this grass is the ornamental one(12). From comments of rural people in Chihuahua, the pink color of the inflorescences is very attractive so they are cut and transported to other places. Once they are dry, they are discarded which contributes to their dispersion.

\section{Control}

One of the alternatives for the control of invasive plants is the use of fire. However, in some grassland where the botanical composition of natal grass was $82 \%$, burning did not reduce this dominance(67). Very likely, under these conditions the plant may behave as an annual, and when the adult plant dies, there are new seedlings. This characteristic of adaptation to fire has been observed in other invasive species in North America $(22,68,69)$. In other studies, it has been reported that fire increases the probability of natal grass invasion(5). Therefore the use of fire for the control of natal grass, as well as other annual grasses must be considered with caution.

There are no reports of control of natal grass through herbicides or chemical products. This may be due to the high costs in the use of these products as well as to the high environmental risks involved.

\section{CONCLUSIONS}

Natal grass has adapted to different kinds of habitats in Mexico and around the world. Despite being an invasive species of fast expansion, there is a lack of information about its biology, uses and control. Anthropogenic activities are the main cause for its distribution, since it has been determined that, as well as many invasive species, it develops better in places subject to 
espigas y las trasportan a otros lugares. Una vez secas, las espigas son desechadas, lo que contribuye a su dispersión.

\section{Control}

Una de las alternativas de control de plantas invasoras es el uso del fuego. Sin embargo, en un pastizal donde la composición botánica del pasto rosado era de $82 \%$, las quemas no redujeron esta dominancia(67). Muy probablemente, bajo estas condiciones la planta se puede comportar como anual y, si bien la planta adulta muere, se presenta un reclutamiento de nuevas plántulas. Esta característica de adaptación al fuego se ha observado con otras especies invasoras en Norteamérica $(22,68,69)$. En otros trabajos se ha reportado que el fuego incrementa la probabilidad de invasión del pasto rosado(5). Por lo tanto, el uso de fuego para el control del pasto rosado, como de otras gramíneas anuales, debe ser considerado con cautela.

No existen reportes de control del pasto rosado por medio de herbicidas o productos químicos. Quizá esto se deba a los altos costos en el uso de estos productos así como a los riesgos ambientales involucrados.

\section{CONCLUSIONES}

El pasto rosado se ha adaptado a diversos tipos de hábitats en México y alrededor del mundo. A pesar de ser una especie invasora de rápida expansión, falta información sobre su biología, aprovechamiento y control. Las actividades antropogénicas son la principal causa para que continúe su distribución, ya que se ha determinado que, como muchas invasoras, se desarrolla mejor en lugares sujetos a disturbios, como a lo largo de caminos y de ahí invade a diferentes ecosistemas.

La opinión de los ganaderos no está bien definida, pues mientras los que cuentan con pastizales dominados con el pasto rosado representa una fuente de forraje; en los ranchos disturbance, such as along highways, and from there it invades different ecosystems.

The ranchers' opinion is not well defined, since those who have range lands dominated by natal grass find it a source of forage; in ranches with native vegetation, natal grass is a threat. Although plant invasions may reduce economic production in a place, they also contribute to maintain the ecosystem's functions. The lack of information about the influence of natal grass both in the ecosystem's structure and functionality limits the economic and ecologic quantification of the impact of the invasions in production systems and environmental services. The quantification of these impacts may give greater relevance to management or control plans for this species. As part of a natal grass control campaign, information programs for the general public may be constructed as they have done for other species so at least the transfer of the germplasm from one place to another is avoided. The government agencies in charge of controlling grazing or plant extraction must apply the current regulations to ensure that the ecosystems keep a proper vegetation cover that does not foster the establishment of exotic species. Finally it is important to look for new ways of using this species which is already naturalized in Mexico as well as in other parts of the world.

End of english version

con vegetación nativa, el rosado es una amenaza. Si bien, las invasiones de plantas puedan reducir la producción económica en un sitio, también contribuyen a mantener las funciones del ecosistema. La falta de información sobre la influencia del pasto rosado tanto en la estructura como en la funcionalidad del ecosistema limita cuantificar económica y ecológicamente el impacto de las invasiones en los sistemas de producción y servicios ambientales. La cuantificación de estos impactos 
Alicia Melgoza Castillo, et al. / Rev Mex Cienc Pecu 2014;5(4):429-442

daría mayor peso a planes de manejo o control de esta especie. Indudablemente que como parte de una campaña de control del pasto rosado se pueden integrar programas de información al público en general, como se ha hecho con otras especies para, al menos, evitar la transferencia de germoplasma de un lugar a otro. Las agencias de gobierno encargadas de controlar el pastoreo o extracción de vegetación deben aplicar la actual normatividad para asegurar que los ecosistemas mantengan una cubierta vegetal adecuada que no favorece el establecimiento de especies exóticas. Por último es importante la búsqueda de nuevas formas de aprovechamiento de esta especie ya naturalizada en México, como en otras partes del mundo.

\section{LITERATURA CITADA}

1. Kooij MS, Bredenkamp GJ, Theron GK. The plant communities of the hills and ridges in the north western Orange free State, South Africa. Bot Bull Acad Sinica 1990;31(4):295-304.

2. Grobler $\mathrm{CH}$, Bredenkamp GJ, Brown LR. Natural woodland vegetation and plant species richness of the urban open spaces in Gauteng, South Africa. Koedoe 2002;45(1):1934.

3. Daemane ME, Cilliers SS, Bezuidenhout H. Classification and description of the vegetation in the Spitskop area in the proposed Highveld National Park, North West Province, South Africa. Koedoe. doi:10.4102/ koedoe.v5i1.1020. 2012.

4. Stokes CA, MacDonald GE, Adams CR, Langeland KA, Miller DL. Seed biology and ecology of natal grass (Melinis repens). Weed Sci 2011;59(4):527-532.

5. David AS, Menges ES. Microhabitat preference constrains invasive spread of non-native natal grass (Melinis repens). Biol Invasions 2011;13(10):2309-2322.

6. Stevens J M, Fehmi JS. Competitive effect of two nonnative grasses on a native grass in southern Arizona. Invasive Plant Sci Manage 2009;2(4):379-385.

7. Possley J, Maschinski J. Competitive effects of the invasive grass Rhynchelytrum repens (Willd.) C.E. Hubb. on pine rockland vegetation. Nat Areas J 2006;26(4):391-395.

8. Pysek P, Richardson DM, Rejmanek M, Webster GL, Williamson $M$, Kirschner J. Alien plants in checklist and floras: towards better communication between taxonomists and ecologists. Taxon 2004;53(1):131-143.

9. FLEPPC. Florida Exotic Pest Plant Council's 2011 List of invasive plant Species. http://www.fleppc.org/list/ 2011PlantList.pdf Accesed Nov 05, 2012.
10. Cárdenas ME. Autoecología del pasto "Natal" Rhynchelytrum roseum (Nees) Stapf y Hubb [tesis licenciatura]. México: Universidad Autónoma de Nuevo León, Monterrey, NL; 1977.

11. Sánchez O. La flora del valle de México. México, D.F: Editorial Herrero, SA; 1978.

12. Cantú JE. 150 gramíneas del norte de México. Universidad Autónoma Agraria Antonio Narro. Torreón, Coah. 1989.

13. Valdés J, Beetle AA, González MH. Gramíneas de Chihuahua. Boletín Pastizales. 1975;8:1-60.

14. Lebgue T, Valerio A. Manual para identificar las gramíneas de Chihuahua. Talleres gráficos del gobierno del estado de Chihuahua. Chihuahua, Chih. 1986.

15. CONABIO. Comisión Nacional para el Conocimiento y Uso de la Biodiversidad. Malezas de México. http:// www.conabio.gob.mx/malezasdemexico/ poaceae/ rhynchelytrum. Consultado Mayo 21, 2012.

16. Chivinge OA. A weed survey of arable lands of thesmallscale farming sector of Zimbabwe. Zomte/a 1988;15(2):167179.

17. Moraes MG, Chatterton NJ, Harrison PA, Filgueiras TS, Figueiredo-Ribeiro RCL. Diversity of non-structural carbohydrates in grasses (Poaceae) from Brazil. Grass Forage Sci 2012;68(1):165-177.

18. Zuloaga FO, Morrone O, Davidse G, Filgueiras TS, Peterson PM, Soreng RJ, Judziewicz E. Catalogue of the new world grasses (Poaceae): III. Subfamilies Panicoideae, Aristioideae, Arundinoideae, and Danthonioideae. Contr. U.S. Natl. Herb. 2003; 46:1-662.

19. March IJ, Martínez MJ. Especies invasoras de alto impacto a la biodiversidad. Prioridades en México. IMTA-CONABIOGECl-Arid América-The Nature Conservancy. Jiutepec, Mor. 2007.

20. Díaz RA, Flores E, De Luna A, Luna JJ, Frías JT, Olalde V. Biomasa aérea, cantidad y calidad de semilla de Melinis repens (Willd.) Zizka, en Aguascalientes, México. Rev Mex Cienc Pecu 2012;3(1):33-47.

21. Carrillo SS, Arredondo T, Huber-Sannwald E, Flores J. Comparación en la germinación de semillas y crecimiento de plántulas entre gramíneas nativas y exóticas del pastizal semiárido. Téc Pecu Méx 2009;47(3):299-312.

22. Butler DW, Fairfax RF. Buffel grass and fire in a Gidgee and Brigalow woodland: a case study from central Queensland. Ecol Manage Rest 2003;4(2):120-125.

23. De la Barrera E. Recent invasion of buffel grass (Cenchrus ciliaris) of a natural protected area from the southern Sonoran Desert. Rev Mex Biodiv 2008;79(2):385-392.

24. Arriaga L, Castellanos AE, Moreno E, Alarcón J. Potential ecological distribution on alien invasive species and risk assessment: a case study of buffel grass in arid regions from Mexico. Conservation Biol 2004;18(6):1504-1514.

25. Correll DS, Johnston MC. Manual of the vascular plants of Texas. Texas Research Foundation. Renner, TX. 1970.

26. Beetle A, Johnson D, Navarro A, Alcaraz R. Gramíneas de Sonora. SARH. Gobierno del estado de Sonora. Hermosillo, Son. 1991.

27. Herrera AY, Pármanes DS. Guía de pastos para el ganado del Estado de Durango. IPN-CIIDIR. Durango, Dgo. 2006. 
28. Lebgue T. Gramíneas de Chihuahua, manual de identificación. Textos Universitarios. Universidad Autónoma de Chihuahua. Chihuahua, Chih. 2002.

29. Melgoza A, Morales C, Sierra JS, Royo MH, Quintana G, Lebgue T. Manual práctico para la identificación de las principales plantas en los agostaderos de Chihuahua. UGRCH-Fundación PRODUCE. Chihuahua, Chih. 2008.

30. Herrera AY, Pármanes DS. Guía de pastos de Zacatecas. CONABIO. IPN-CIIDIR. Zacatecas, Zac. 2010.

31. Sánchez JJ. Caracterización de hábitat y riesgo de invasión por zacate rosado (Melinis repens) en pastizales áridos y semiáridos de Chihuahua, México. [tesis maestría]. México: Universidad Autónoma de Chihuahua; 2012.

32. Zerebeckl RA, Sorte CJS. Temperature tolerance and stress proteins as mechanisms of invasive species success. PLoS one. doi:10.1371 /journal. pone.0014806. 2011.

33. Van Klunen $M$, Schlaepfer DR, Glaettli M, Fischer $M$. Preadapted for invasiveness: do speciestraits or their plastic response to shadingdiffer between invasive and noninvasiveplant species in their native range? J Biogeogr 2011;38(7):1294-1304.

34. Stout JC. Reproductive biology of the invasive exotic shrub, Rhododendron ponticum L. (Ericaceae). Bot J Linnean Soc 2007; 155(3):373-381.

35. Zhang R, Heberling JM, Haner E, Shia K. Tolerance of two invasive thistles to repeated disturbance. Ecol Res 2011;26(3):575-581.

36. Küster EC, Kühn I, Bruelheide H, Klotz S. Trait interactions help explain plant invasion success in the German flora. J Ecol 2008;96(5):860-868.

37. Ward SM, Gaskin FF, Wilson LM. Ecological genetics of plant invasion: What do we know? Invasive Plant Sci Manage 2008; 1(1): 98-109.

38. Williams DG, Baruch Z. African grass invasion in the Americas: ecosystem consequences and the role of ecophysiology. Biol Invasions 2000;2(2):123-140.

39. Craig RM. Native vegetation along constructed channels in peninsular Florida. Proc Fla State Hort Soc 1978;91:85-88.

40 Murray BR, Phillips ML. Investment in seed dispersal structures is linkedto invasiveness in exotic plant species of south-eastern Australia. Biol Invasions 2010;12(7):22652275.

41 Pergl J, Müllerová J, Perglová I, Herben T, Pysek P. The role of long-distance seed dispersalin the local population dynamics of aninvasive plant species. Diversity Distrib 2011;17(4): 725-738.

42. Hernández NS. Viabilidad y Crecimiento del Zacate Rosado (Melinis repens (Willd.) Zizka) [tesis maestría]. México: Universidad Autónoma de Chihuahua; 2009.

43. Hierro JL, Eren Ö, Khetsuriani L, Diaconu A, Török K, Montesinos D, et al. Germination responses of an invasive species in native and non-native ranges. Oikos 2009; 118(4):529-538.

44. Waller SS, Lewis JK. Ocurrence of $C$ nas $C$ pathways in North America grasses. J Range Manange 1979;32(1):1228.

45. Mata-González R, Sosebee RE, Wan C. Shoot and root biomass of desert grasses as affected by biosolids application. J Arid Environ 2002;50(3):477-488.
46. Dalrymple RL, Dwyer D. Root and shoot growth of five range grasses. J Range Manage 1967;20(3):141-145.

47. Evans TL, Mata-Gonzalez R, Martin DW, McLendon T, Noller JS. Growth, water productivity, and biomass allocation of Great Basin plants as affected by summer watering. Ecohydrology. DOI: 10.1002/eco.1291. 2012.

48. Arredondo JT, Jones TA, Johnson DA. Seedling growth of intermountain perennial and weedy annual grasses. J Range Manage 1998;51(5):584-589.

49. James JJ, Drenovsky RE. A basis for relative growth rate differences between native and invasive forb seedlings. Rangeland Ecol Manage 2007;60(4):395-400.

50. Mata-González R, Melendez-Gonzalez R. Growth characteristics of Mexican oregano (Lippia berlandieri) under salt stress. Southwest Nat 2005;50(1):1-6.

51. Leoni E, Altesor A, Paruelo J M. Explaining patterns of primary production from individual level traits. J Veg Sci 2009;20(4):62-619.

52. Kroon H, Hendriks M, van Ruijven J, Ravenek J, Padilla FM, Jongejans E, Visser EJW, Mommer L. Root responses to nutrients and soil biota: drivers of species coexistence and ecosystem productivity. J Ecol 2012;100(1):6-15.

53. Jordan NR, Larson DL, Huerd SC. Evidence of qualitative differences betweensoil-occupancy effects of invasive vs. native grassland plant species.Invasive Plant Sci Manage 2011;4(1):11-21.

54. Vanderhoeven S, Dassonville N, Meerts P. Increased topsoil mineral nutrient concentrations under exotic invasive plants in Belgium. Plant Soil 2005;275(1-2):169-179.

55. Souza L, Velini ED, Maimoni-Rodella RCS, Martins D. Teores de macro e micronutrientes e a relação $\mathrm{C} / \mathrm{N}$ de varias espécies de plantas daninhas. Planta Daninha 1999;17(1):163-167.

56. Galyean M.L. Laboratory procedures in animal nutrition research. Depto. of Animal and Food Science. Texas Tech University. Lubbock, TX. 1980.

57. Morales CR, Madrid L, Melgoza A, Martínez M, Arévalo S, Rascón Q, Jurado P. Análisis morfológico de la diversidad del pasto navajita [Bouteloua gracilis (Willd. ex Kunth) Lag. ex Steud.], en Chihuahua, México. Téc Pecu Méx 2009;47(3):245-256.

58. Chávez AH, González FJ. Estudios zootécnicos I (animales en pastoreo). En: A.H. Chávez S. (compilador). Rancho Experimental La Campana 50 años de investigación y trasferencia de tecnología en pastizales y producción animal. Libro Técnico No. 2. Chihuahua, Chih. 2008;113-183.

59. Báez AD, Reyes JG, Melgoza A, Royo MH, Carrillo R. Características productivas del sistema vaca-cría en el estado de Chihuahua. Téc Pecu Méx 1999;37(1):11-24.

60. Perkins LB, Johnson DW, Nowak RS. Plant-induced changes in soil nutrient dynamics by native and invasive grass species. Plant Soil 2011;345(1-2):365-374.

61. Kivlin SN, Hawkes CV. Differential between effects of invasion and diversity: impacts of aboveground plant communities on belowground fungal communities. New Physiologist 2011;189(2):526-535.

62. Crawford KM, Rudgers JA. Plant species diversity and genetic diversity within a dominant species interactively affect plant community biomass. J Ecol 2012;100(6):1512-1521. 
Alicia Melgoza Castillo, et al. / Rev Mex Cienc Pecu 2014;5(4):429-442

63. Souza L, De Paula A, Figueiredo-Ribeiro RC. Effects of irradiance on non-structural carbohydrates, growth, and hypoglycemic activity of Rhynchelytrum repens (Willd.) C.E. Hubb. (Poaceae). Braz J Biol 2004;64(3):697-706.

64. De Paula AC, Sousa RV, Figueiredo-Ribero RC, Buckeridge MS. Hypoglycemic activity of polysaccharide fractions containing B-glucans fromextracts of Rhynchelytrum repens (Willd.) C.E. Hubb., Poaceae. Braz J Med Biol Res 2005;38(6):885-893.

65. Pratt C, Lottermoser BG. Trace metal uptake by the grass Melinis repens from road sides oils and sediments, tropical Australia. Environ Geol 2007;52(8):1651-1662.

66. Carneiro MA, Siqueira JO, Moreira FMS. Comportamento de espécies herbáceas em misturas de solo com diferentes graus de contaminação com metais pesados. Pesq Agropec Bras 2002;37(11):1629-1638.

67. Miranda R. Aplicación de fuego prescrito para el control del zacate rosado (Melinis repens). (tesis licenciatura) México. Universidad Autónoma de Chihuahua. Chihuahua, Chih. 2012.

68. Mata-González R, Hunter RG, Coldren CL, McLendon T, Paschke M. Modelling plant growth dynamics in sagebrush steppe communities affected by fire. J Arid Environ 2007;69(1):144-57.

69. Mata-González R, Hunter RG, Coldren $\mathrm{CL}$, McLendon $\mathrm{T}$, Paschke MW. A comparison of modeled and measured impacts of resource manipulations for control of Bromus tectorum in sagebrush steppe. J Arid Environ 2008; 72(5):836-46. 